\title{
Predictive diagenetic clay-mineral distribution in siliciclastic rocks as a tool for identifying sequence boundaries in non-marine successions: the Coalspur Formation, west-central Alberta
}

\author{
Ahmed KHidir ${ }^{1} \&$ Octavian Catuneanu ${ }^{2}$ \\ ${ }^{1}$ EnCana Corporation, Calgary, Alberta, Canada T2P 2S5; \\ e-mail: Ahmed.Khidir@encana.com \\ ${ }^{2}$ Department of Earth and Atmospheric Sciences, University of Alberta, Edmonton, Alberta, Canada T6G 2E3
}

\begin{abstract}
The study of upper Cretaceous - lower Tertiary fluvial deposits of the Coalspur Formation in the Foothills region of west-central Alberta reveals that the distribution of early authigenic kaolinite has a well-defined relation to the sequence stratigraphic framework. In this context, it has been observed that the kaolin mineral content increases in sandstones lying below subaerial unconformities, which mark the most significant stratigraphic hiatuses and hence the sequence boundaries in fully fluvial successions. The increased abundance of authigenic kaolinite immediately below sequence boundaries may have been caused by the infiltration of meteoric water during times of subaerial erosion, resulting in the dissolution of unstable minerals (e.g., micas and feldspar) and the formation of kaolinite and secondary porosity. It is therefore suggested that the change in clay mineral assemblages in the stratigraphic section depends in part on the position of the analyzed sandstone samples relative to the sequence boundaries. In a larger context, the method of using authigenic clays to delineate depositional sequences in non-marine successions needs to be evaluated on a caseby-case basis, as the diagnostic early diagenetic minerals underlying the sequence boundary may change as a function of palaeoclimate and also as a function of late diagenetic processes.
\end{abstract}

Keywords: sequence stratigraphy, non-marine deposits, siliciclastics, diagenesis, clay minerals

\section{Introduction}

The application of sequence stratigraphy to a continental setting results in an improved understanding of the variation in the facies architecture of fluvial deposits; in turn, this implies a better prediction of the development of hydrocarbon fluvial reservoirs. Many studies have demonstrated the close association between fluvial stratigraphic traps and sequence boundaries that are surfaces of subaerial erosion (Wu et al., 1998; Luebking et al., 2001). Various authors have also examined and described the characteristics of diagenesis in the vicinity of unconformities, with emphasis on reservoir properties (Garcia, 2000; Csoma et al., 2004).

The relation between sequence stratigraphy and the distribution of authigenic cement in sandstone is predictable because changes in the 
detrital composition and pore water chemistry often occur at sequence stratigraphic surfaces (Morad et al., 2000; Ketzer et al., 2002, 2003a). Thus, knowledge of sequence stratigraphy and sequence stratigraphic surfaces in particular can provide useful information on parameters controlling near-surface diagenesis. Integrating sequence stratigraphy and diagenesis can help improve the prediction of the distribution of diagenetic minerals in sandstones and, hence, the evolution of reservoir quality (Morad et al., 2000; Ketzer et al., 2002, 2003b).

Authigenic clay minerals such as kaolinite, dickite, smectite, and non-clay minerals such as quartz overgrowths and calcite cement in sandstones are studied in the present contribution. These minerals are important from the petroleum geology perspective; they provide a complete picture of diagenetic history, and control reservoir properties such as porosity, permeability and water saturation. Authigenic minerals may also provide indications of the palaeo-environmental and palaeoclimatic conditions that prevailed during the development of unconformities. The aim of the current paper is to: (1) confirm the position of the sequence boundary in the study succession; (2) discuss the role of sequence stratigraphic controls on sandstone diagenesis and, hence, on reservoir properties; and (3) define a predictive model for the distribution of early diagenetic clay minerals in fluvial sandstones within a sequence stratigraphic framework.

\section{Geological background}

Late Maastrichtian - Early Palaeocene strata of the Coalspur Formation in the Western Canada foredeep (Fig. 1) form a fully non-marine depositional sequence bounded by regional subaerial unconformities (Fig. 2). The Coalspur Formation overlies the Brazeau Formation and is overlain by the Paskapoo Formation (Fig. 2). Jerzykiewicz and McLean (1980) and Jerzykiewicz (1997) suggested that the upper unconformable boundary be placed at the base of the lowest major sandstone bed above the highest thick coal seam (Val d'Or) of the Coalspur coal zone. Magneto-biostratigraphic studies of Ler-

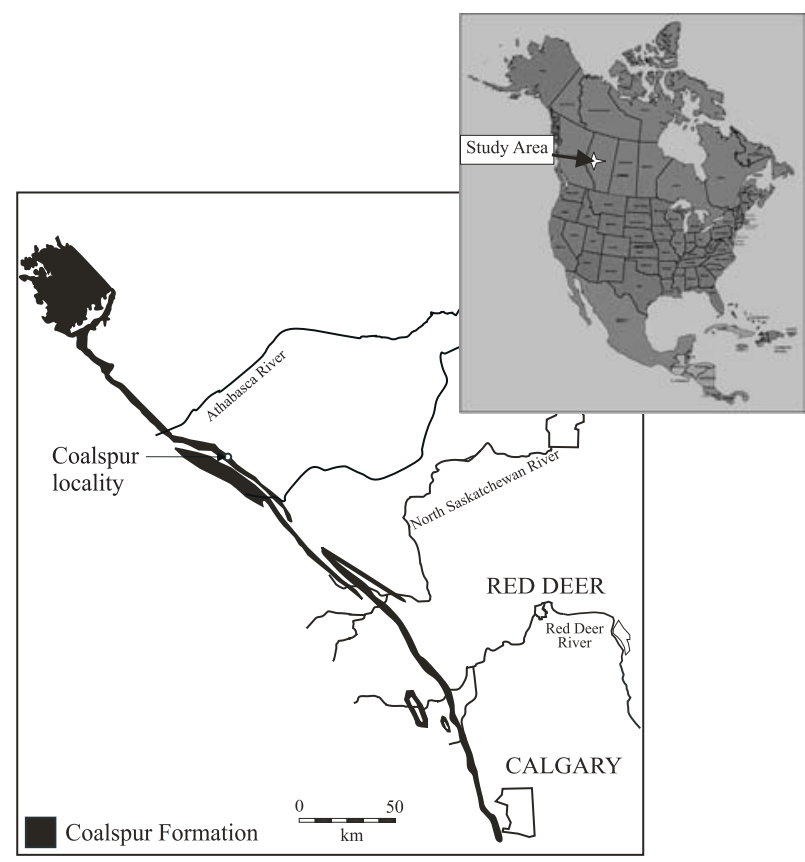

Fig. 1. Outcrop distribution of the Coalspur Formation in Alberta, and the location of the studied outcrop section.

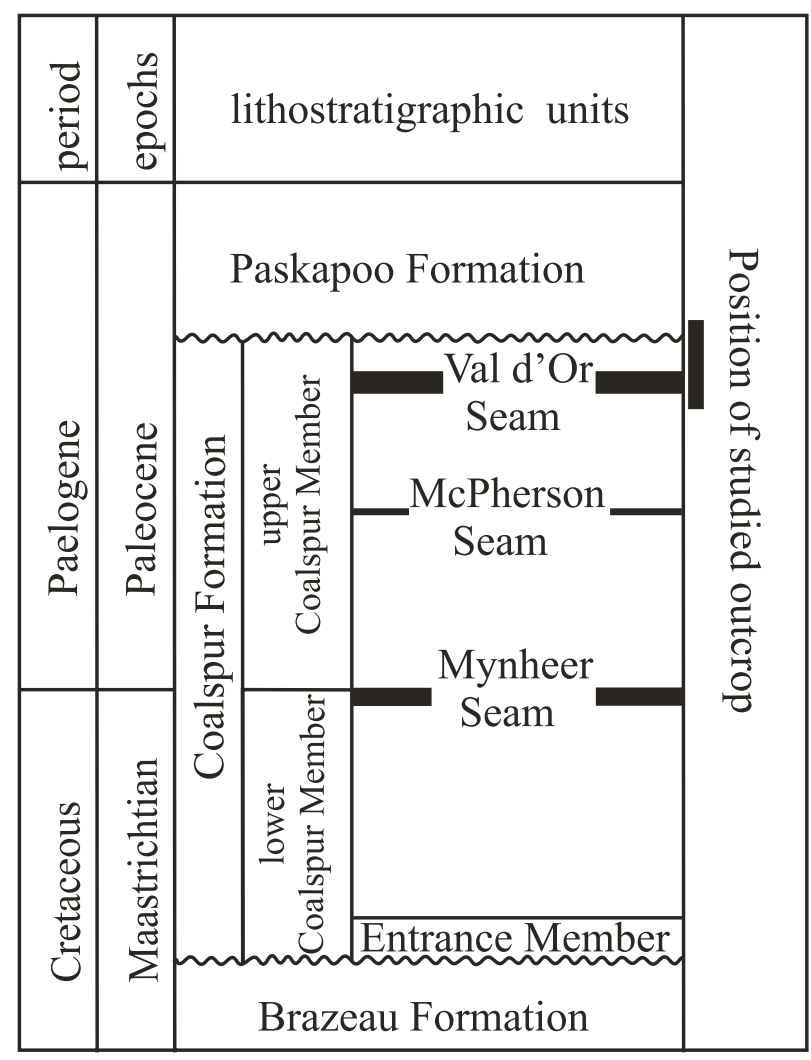

Fig. 2. Generalized chart of the late Maastrichtian-Paleocene stratigraphy of west-central Alberta, showing the position of the upper Coalspur Formation and its main coal seams. 
bekmo and Sweet (2008) also concluded the most likely position of the Coalspur/Paskapoo sequence boundary was directly above the top of the Val d'Or coal seam, and at the base of the lowest sandstone directly above the "burned zone" (Fig. 2).

The lower unconformable boundary occurs at the sub-Entrance conglomerate unconformity (Fig. 2). On the basis of palynology and an iridium anomaly, the Cretaceous-Tertiary boundary was defined within the Coalspur Formation at the base of the Mynheer coal seam (Jerzykiewicz et al., 1984; Jerzykiewicz \& Sweet, 1986). Coalspur Formation correlates with the Scollard Formation of the Plains region and the Willow Creek Formation in southwestern Alberta. This correlation is constrained in part by the occurrence of the Cretaceous-Tertiary boundary, which divides these formations into upper and lower parts. The depositional environment of the Coalspur Formation was dominated by fluvial systems sourced from the adjacent Cordilleran belt, with additional sedimentation in lacustrine and swamp environments.

The Coalspur Formation was defined and mapped in the central Foothills between the Athabasca River and the Coal Valley (Jerzykiewicz \& Sweet, 1986) (Fig. 1). The upper part of the formation in the vicinity of the Coalspur section, from the McPherson coal seam up to the upper unconformable contact with the Paskapoo Formation (Fig. 2) was also described and studied by Jerzykiewicz and Maclean (1980), Jerzykiewicz and Langenberg (1983), and Jerzykiewicz and Sweet (1986, 1988).

The Coalspur Formation accumulated in a predominantly fluvial and lacustrine environments. Deposition of the Coalspur Formation in the Alberta foredeep corresponds to a period of loading in the thrust-fold belt which created accommodation (Catuneanu and Sweet, 1999). Sedimentation continued until the beginning of Eocene time. At the beginning of the Eocene epoch, subsidence of the foreland basin was replaced by isostatic uplift resulting in the erosion of more than $1000 \mathrm{~m}$ of postPalaeocene sediments from the foreland basin (Nurkowski, 1984; Dawson et. al., 1994). Thus, the Coalspur Formation was subject to deep burial followed by significant uplifting and the formation was probably buried deeper than 2 $\mathrm{km}$ prior to Palaeocene time.

\section{Non-marine sequence stratigraphy}

Sequence stratigraphy is a genetic approach to the subdivision of the stratigraphic record into sequences based on how depositional systems respond to changes in the space available for sediment accumulation that is termed 'accommodation' (Posamentier et al., 1988). Fluvial accommodation may be modified by downstream controls (i.e., base-level change) and upstream controls (i.e., source area tectonism and climate) (e.g., Aitken \& Flint, 1995; Miall, 1997; McCarthy \& Plint, 1998; Catuneanu, 2006). Lowering of the fluvial equilibrium (graded) profile (i.e., negative fluvial accommodation) leads to fluvial channel incision, which results in the development of a regional unconformity termed a "sequence boundary" (Posamentier \& Vail, 1988; Shanley \& McCabe, 1994).

Fluvial accommodation during the deposition of the Coalspur Formation was modified by upstream controls, primarily flexural tectonism (Catuneanu \& Sweet, 1999; Catuneanu et al., 2000). Differential subsidence across the foredeep of the Alberta basin, with higher subsidence rates towards the thrust-fold belt, generated a gradual shallowing of the topographic gradient during orogenic loading, and resulted in a shift in fluvial depositional elements from braided channels (lower Coalspur) to isolated meandering channels, crevasse splays and overbank fines (upper Coalspur). Regional isostatic rebound during stages of orogenic quiescence has been proposed as the cause for the formation of fluvial sequence boundaries within the Alberta foredeep (Catuneanu \& Sweet, 1999; Catuneanu et al., 2000). Based on the ratio between fluvial depositional elements, the Coalspur Formation may be subdivided into two fluvial systems tracts, which are the (channel-dominat- 
ed) low-accommodation systems tract of the lower Coalspur Formation, and the (low-energy fluvial and lacustrine-dominated) highaccommodation systems tract of the upper Coalspur Formation.

\section{Methods}

Fieldwork was carried out in west-central Alberta in the Coalspur locality and outcrop section was studied in detail (Fig. 1). Standard logging techniques were applied, including thickness measurements, facies analysis, and sampling for laboratory work. Twenty-five sandstone samples were impregnated with blue epoxy resin to highlight porosity before preparing the thin-section slides. Representative thin-sections were point-counted (250 points) to calculate the relative amounts of detrital framework grains, interstitial minerals, and porosity. The grain size was estimated in millimetre units, and sorting was estimated by comparison with published sorting comparators (Longiaru, 1987).

To identify clay minerals, porosity, and to determine paragenesis, selected samples were studied and examined by scanning electron microscope (SEM, JEOL JSM 6400) equipped with an energy-dispersive $x$-ray analyzer. To determine the modal amount and types of authigenic clay minerals, a grinding technique was used to produce powders free of grains coarser than $20 \mu \mathrm{m}$. X-ray diffraction (XRD) was preformed on the bulk samples and on samples finer than $2 \mu \mathrm{m}$. The resulting diffraction data was then analyzed using the industry standard MDI Jade software and the CDD PDF-2 powder diffraction database. Two equal fractions of each sample were selected for bulk analysis and for the analysis of the less than $2 \mu \mathrm{m}$ particles. Diffraction data on the resulting clay slides were acquired. The relative abundance of specific clay minerals within the clay fraction was determined using the data obtained on the $<2 \mu \mathrm{m}$ clay fraction. The criteria of Wilson and Pittman (1977) were used to differentiate between detrital and authigenic clay minerals.

\section{Results}

\section{Sandstone petrography}

The sandstones consist mainly of quartz and rock fragments with small amounts of feldspar grains. Monocrystalline quartz averages $50 \%$ of the framework grains (Fig. 3A), whereas rock fragments, which are of igneous (Fig. 3A), metamorphic (Fig. 3B), and sedimentary origin (Fig. $3 C)$, make up $45 \%$ of the framework grains. Feldspar has less abundance (Fig. 3D) and averages $5 \%$ of the framework grains. Accessory minerals such as muscovite also occur (Fig. 3C). The sandstones range from fine- to medium-grained and display moderate sorting. Based on Pettijohn et al.'s (1987) classification, the sandstones of the Coalspur locality are defined as litharenites to sublitharenites (Fig. 4) and characterized by a general lack of matrix.

\section{Authigenic mineral distribution}

The dominant authigenic minerals in the sandstones are the kaolin minerals (i.e., kaolinite and dickite; Fig. 6), with subordinate quartz overgrowth, calcite, smectite, and mixed layer illite/smectite (Figs. 3E and 5C and D).

Kaolinite and dickite are the most widespread authigenic clay minerals in the sandstones (Fig. 5A and B). Kaolinite generally formed at low temperatures $\left(<120^{\circ} \mathrm{C}\right)$ during weathering and diagenetic processes, and occurs as pore filling pseudohexagonal crystals with booklet and vermicular shapes (Fig. 5A). The kaolinite in the sandstones may have precipitated during the Tertiary uplift due to abundant groundwater flow through the porous sandstones. Dickite, which reflects an increase in burial temperature and pressure (Shutov et al., 1970; Ehrenberg et al., 1993), occurs as blocky pseudohexagonal crystals (Fig. 5B). The aggregation of dickite crystals increases significantly in the sandstones below the first conglomerate bed above the last coal zone of the Coalspur Formation (Fig. 6). 

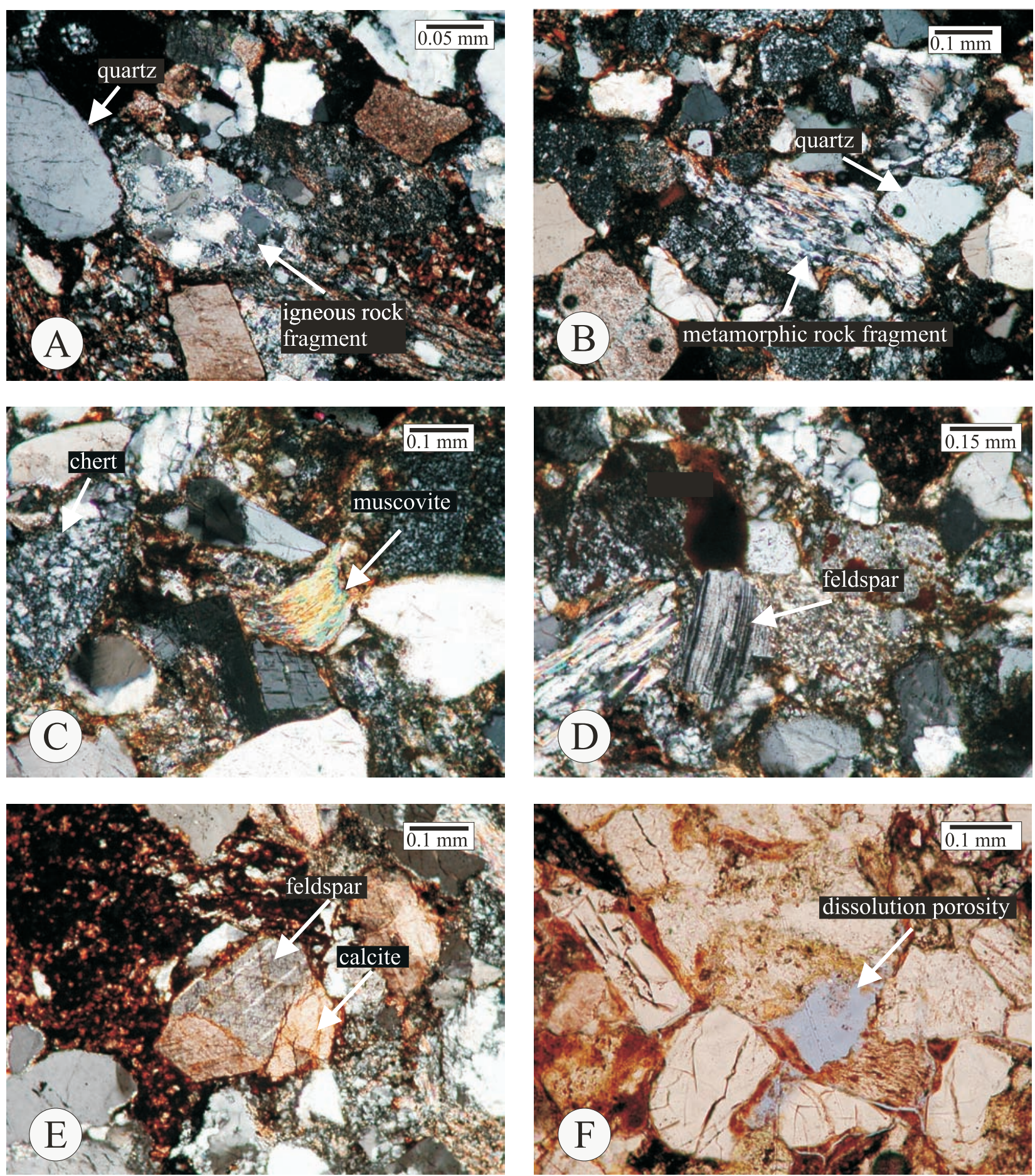

Fig. 3. Thin-section photomicrographs: (A) - litharenite with igneous rock fragments and quartz grains. (sample 1, upper Coalspur Formation, Coalspur locality); (B) - detrital grain of metamorphic origin (sample 3, upper Coalspur Formation, Coalspur locality); (C) - detrital chert of sedimentary origin and muscovite grain. Note the uniform microcrystalline quartz with no visible relict texture. (sample 2, upper Coalspur Formation, Coalspur locality); (D) - twinned plagioclase feldspar grain (sample 1, upper Coalspur Formation, Coalspur locality); (E) - feldspar grain and calcite cement filling the pore-space (arrow) (sample 6, upper Coalspur Formation, Coalspur locality); (F) - secondary porosity resulting from dissolution of probable feldspar grain (arrow) (sample 8, upper Coalspur Formation, Coalspur locality). 


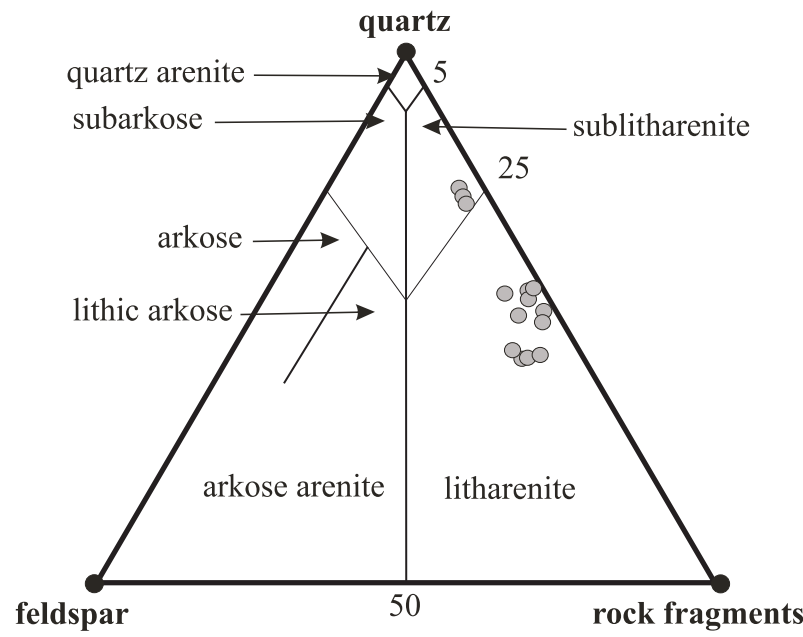

-Upper Coalspur Member

Fig. 4. Classification of the upper Coalspur Formation sandstones (after Pettijohn et al., 1987).

An insignificant amount of authigenic smectite is found in the sandstones (Fig. 6). Mixed layer illite-smectite was observed as well (Fig. 5D).

Authigenic non-clayey minerals in sandstones are quartz overgrowths (Fig. 5C) and calcite cement (Fig. 3E). The quartz overgrowths in the sandstones show no distinct distribution pattern related to the sequence boundary. The calcite cement in the sandstones ranges from patchy to uniform (Fig. 3E). The detailed chemistry of the calcite precipitates is beyond the scope of this paper.

The occurrence of quartz overgrowths (Fig. 5C) may be attributed to the influx of meteoric (acidic) water into the sandstones. The mixing of the meteoric water with alkaline pore water would increase the acidity of the pore water, resulting in a decrease in the solubility of silica and alumina and precipitation of quartz overgrowths, and possibly kaolinite, in the pore systems.

The precipitation of the late diagenetic calcite cement, typically associated with unconformity surfaces, was probably caused by the enrichment of the pore solutions with $\mathrm{Ca} 2++$ and HCO- through the dissolution of Ca-feldspar grains. Carbonate rock fragments - another possible source of calcite cement in the upper Coalspur sandstones, were probably derived from sedimentary strata in the Rocky Mountain Front Ranges. The presence of cal- cite cement in the Coalspur sandstones preferentially below the top unconformity (sequence boundary) may have occurred during subaerial exposure related to isostatic rebound.

\section{Porosity development below the subaerial unconformities}

The sandstone porosity of the outcrop-derived samples determined from thin sections ranges from $3 \%$ to $13 \%$ and averages $10 \%$. The present porosity is secondary in origin. The secondary porosity includes grain moldic porosity produced by the partial dissolution of feldspar along cleavage planes and twin boundaries (Fig. 5E), corrosion of grains adjacent to pores, which are generally the result of the incomplete replacement of feldspar grains.

\section{Discussion}

\section{Position of the sequence boundary at the studied section}

Feldspar leaching and the associated production of abundant kaolinite can be used to infer the past interaction of meteoric water with sandstone and, more generally, that kaolinite is indicative of unconformities (Tardy, 1971; Emery et al., 1990). In this context, the relative abundance of authigenic kaolinite/dickite may be used as an indicator of an unconformity.

By examining the authigenic clay mineral trend in the sandstones we observed a systematic increase in the abundance of authigenic dickite toward the erosional base of the conglomerate bed above the upper coal zone (Fig. 6). The possible scenario that explains the clay-mineralogy trends is that meteoric flushing, which was accompanied by the dissolution of unstable minerals (e.g., feldspar), and consequent authigenic kaolinite precipitation occurred when the Coalspur Formation was subaerially exposed. During subsequent burial diagenesis most of the kaolinite below the 

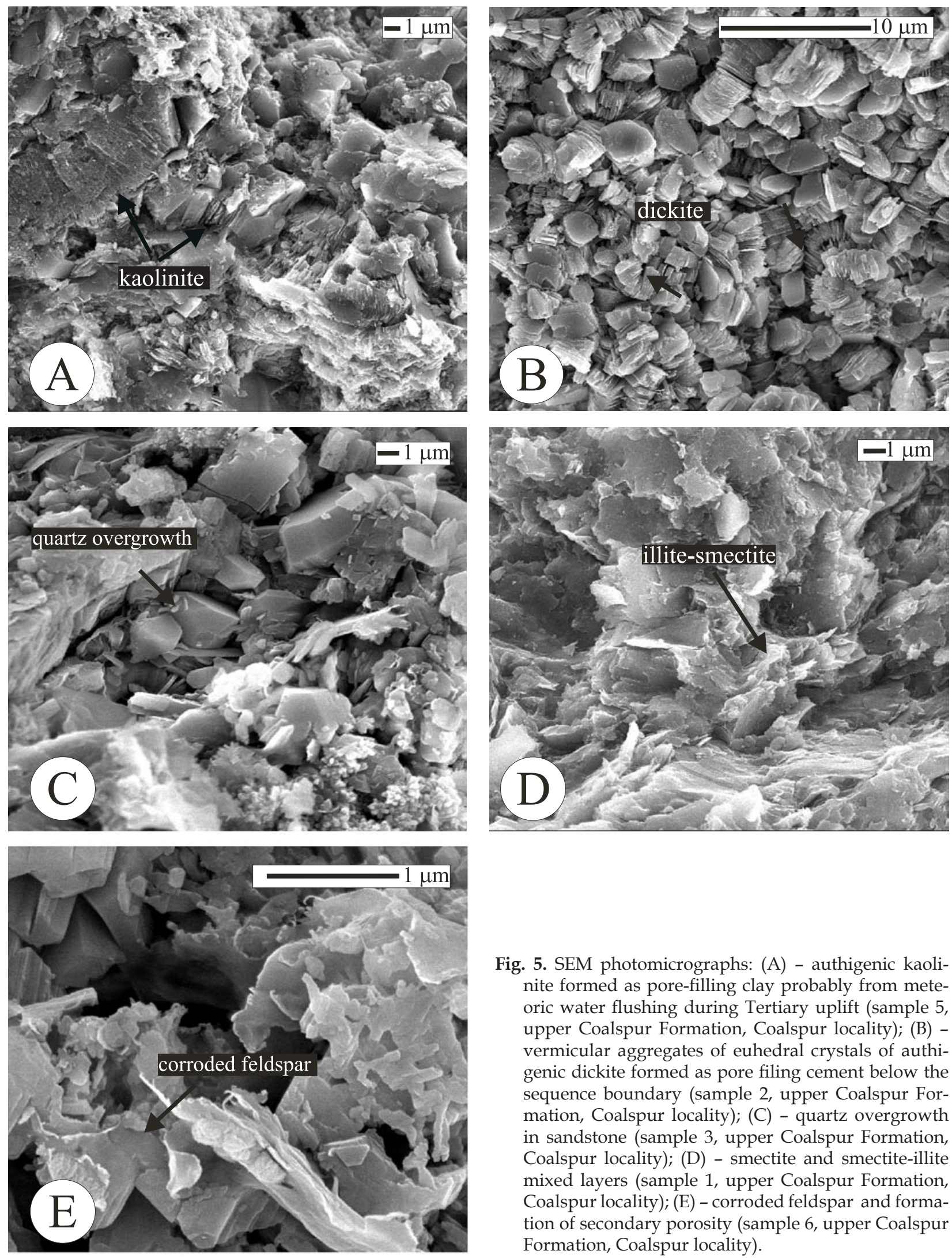

Fig. 5. SEM photomicrographs: (A) - authigenic kaolinite formed as pore-filling clay probably from meteoric water flushing during Tertiary uplift (sample 5, upper Coalspur Formation, Coalspur locality); (B) vermicular aggregates of euhedral crystals of authigenic dickite formed as pore filing cement below the sequence boundary (sample 2, upper Coalspur Formation, Coalspur locality); (C) - quartz overgrowth in sandstone (sample 3, upper Coalspur Formation, Coalspur locality); (D) - smectite and smectite-illite mixed layers (sample 1, upper Coalspur Formation, Coalspur locality); (E) - corroded feldspar and formation of secondary porosity (sample 6, upper Coalspur Formation, Coalspur locality). 


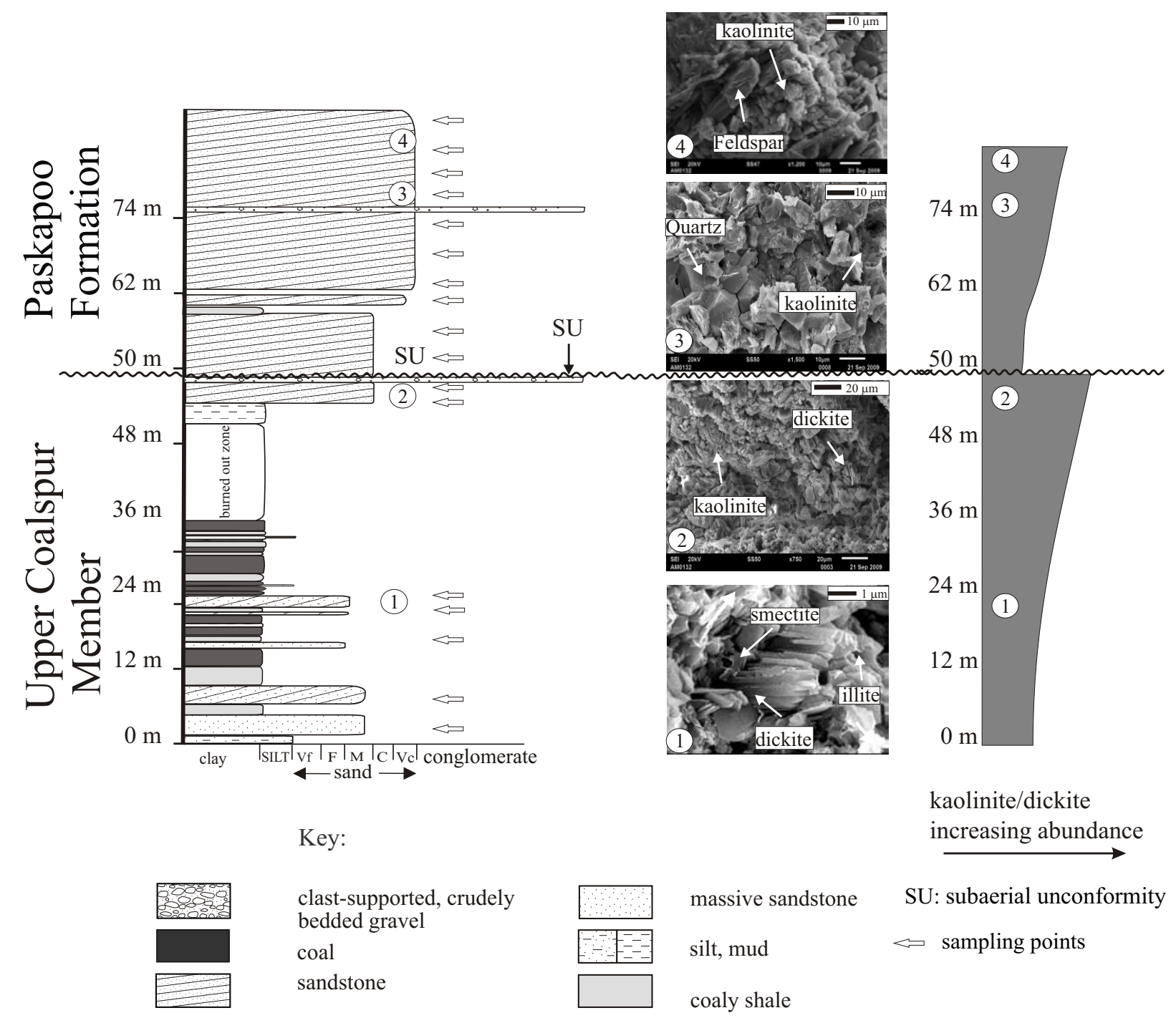

Fig. 6. Vertical lithologic profile for the Coalspur locality section, showing the occurrence and abundance of authigenic kaolin minerals in relation to the sequence boundary as indicated by SEM analyses. Please note that the horizontal scale of studied outcrop is about six meter wide.

unconformity altered to dickite. Thus, the increase in kaolinite/dickite mineral abundance may be taken as a proxy to locate subaerial unconformities, and in this particular case study, the upper boundary of the fluvial Coalspur sequence.

\section{Diagenetic alteration associated with the sequence boundary}

Kaolinite formation, which requires intensive weathering and high rates of water percolation (Weaver, 1989; Robert \& Chamley, 1991), is the main diagenetic alteration related to the sequence boundary in the sandstones of the upper Coalspur Formation. The flushing of meteoric water in the sandstones resulted in a thick zone of intense kaolinitization below the sequence boundary (Fig. 5B). The thick dickite zone suggests significant time of subaerial exposure, and hence stratigraphic hiatus associated with the top-Coalspur unconformity. The thickness of dickite zone may also depend on the porosity of the sandstone, grain size and climate.

In addition to the role of the sequence boundary in controlling the distribution of authigenic kaolinite in the sandstones, the initial permeability of the sandstones and the acidity of the pore water chemistry also play 
a role in kaolinite precipitation. The initial permeability controls water circulation and, consequently, influences the precipitation of kaolinite, whereas the influx of meteoric water and acidic fluids, some of which may have derived from the coalification of organic matter, caused an increase in the acidity of the pore solutions and enhanced kaolinite precipitation (Grim, 1953). This kind of environment could explain the increase of diagenetic kaolinite concentration near the sandstone-coal contacts.

\section{Climate control on diagenesis associated with the subaerial unconformity}

Unconformities in the rock record correspond to periods of non-deposition or erosion during considerable time intervals. During the formation of unconformities, sediments may be subject to erosion, dissolution, and the formation of early authigenic cement. The nature of the early cement below the unconformity is a function of the groundwater chemistry, which in turn may be controlled by climate (Suttner \& Dutta, 1986). Cation-rich clays such as smectite form when the climatic condition is relatively arid, and the resultant ionic concentration in the groundwater is high (Velde, 1985). During high humidity and relatively wet climatic conditions, authigenic kaolinite and quartz cements are abundant (Dutta, 1992).

In the sandstones of the upper Coalspur Formation, the occurrence of authigenic kaolin minerals may be interpreted to reflect the influence of humid climatic conditions on the ground water chemistry. Humid climate conditions during the accumulation of the upper Coalspur sediments are also indicated by the presence of thick coal seams.

The occurrence of smectite probably resulted from the alteration of volcanic rock fragments (Fig. 3A). The conversion of smectite to mixed-layered illite-smectite may indicate an increase in the depth of burial, accompanied by an increase in palaeotemperature gradient.

\section{Evolution of reservoir quality in the sandstones}

Weathering may enhance porosity below unconformities, allowing sandstones to act as hydrocarbon reservoirs and pathways of fluid migration (Shanmugam \& Higgins, 1988; Shanmugam, 1990). The influx of meteoric acidic water into the sandstones below the sequence boundary may result in an increase in intergranular porosity and permeability of the sandstones by the dissolution of feldspar; at the same time, this process may also result in the formation of authigenic minerals such as kaolinite and silica cement (Bjørlykke, 1984; Emery et al., 1990). The development of authigenic pore-filling kaolinite modifies the amounts of available porosity and permeability. The stacked, book-shaped, pseudo-hexagonal kaolin minerals that occur as pore-fillings and coatings act as small particles plugging the pore-throats (especially during production), thereby reducing permeability. The presence of other authigenic minerals such as quartz overgrowths further reduces porosity and permeability.

In the upper Coalspur sandstones, determination of precise reservoir quality evolution below the sequence boundary is difficult, partly due to the complicated diagenetic history and involvement of other parameters such grain size, nature and extent of initial diagenesis, climate, and duration of subaerial exposure. Most of the secondary porosity is interpreted to be formed as a result of feldspar leaching (Fig. 5E) during subaerial exposure from meteoric pore-water circulation associated with formation of kaolinite (Fig. 5A and B). Feldspar leaching and dissolution during transportation and during different stages of diagenesis could also explain the low feldspar abundance in the sandstones. Most of the secondary porosity that was created during early diagenesis by leaching of unstable grains was filled by calcite cement during later burial diagenesis. Another important control on reservoir quality of the Coalspur sandstones is the occurrence of kaolin minerals. Generally, the high abundance of kaolin clay minerals below 
the sequence boundary (Fig. 6) played a strong role in controlling the reservoir quality of the sandstones in term of porosity and permeability; the limited amount of smectite, illite-smectite, and silica cementation had less control on the sandstone's properties in this particular case study.

\section{Conclusions}

1. Diagenetic processes may be related to some extent to the development of specific sequence stratigraphic surfaces. Subaerial unconformities in fluvial settings are particularly prone to control the distribution of diagenetic minerals within the sequence. The nature of the diagenetic minerals below the sequence boundary may in turn depend on the climatic conditions during the formation of the subaerial unconformity.

2. The upper sequence boundary of the Coalspur Formation (i.e., a subaerial unconformity) is underlain by a thick zone of kaolinite/dickite in the sandstones. The precipitation of kaolin minerals below the sequence boundary may be related to flushing of meteoric water and dissolution of unstable minerals during the formation of the subaerial unconformity. Following burial, most of the original kaolinite was transformed into dickite.

3. The occurrence of authigenic kaolin minerals within the Coalspur sequence may be interpreted to reflect the influence of humid climatic conditions on the groundwater chemistry at the time of sedimentation, as well as during subsequent uplift and subaerial erosion. Humid climate conditions are also indicated by the presence of thick coal seams within the upper Coalspur Formation.

4. The observed pattern of distribution of early authigenic clay minerals within a fluvial succession may be used to infer the position of 'cryptic' non-marine sequence boundaries, which lack an evident lithological expression. Integration of diagenesis and sequence stratigraphy also allows for better prediction of reservoir quality in non-marine sequences.

\section{Acknowledgments}

Research funding was provided by the Natural Sciences and Engineering Research Council of Canada (discovery grant to O. Catuneanu). We thank Dan Potocki, Hugh Lavallee and James Park for feedback on earlier versions of the manuscript. Constructive comments and reviews have been provided by Art Sweet, Sergio Longhitano and an anonymous reviewer.

\section{References}

Aitken, J.F. \& Flint, S.S., 1995. The application of highresolution sequence stratigraphy to fluvial systems: a case study from the Upper Cretaceous Breathitt Group, eastern Kentucky, USA. Sedimentology 42, 3-30.

Bjorlykke, K., 1984. Formation of secondary porosity: how important is it? [In:] D.A. McDonald \& R.C. Surdam (Eds): Clastic Diagenesis. American Association of Petroleum Geologists, Memoir 37, 277-286.

Catuneanu, O., 2006. Principles of Sequence Stratigraphy. Elsevier, Amsterdam, 375 pp.

Catuneanu, O., Sweet, A.R., \& Miall, A.D., 2000. Reciprocal stratigraphy of the Campanian-Paleocene Western Interior of North America. Sedimentary Geology 134, 235-255.

Catuneanu, O. \& Sweet, A.R., 1999. MaastrichtianPaleocene foreland basin stratigraphies, Western Canada: A reciprocal sequence architecture. Canadian Journal of Earth Sciences 36, 685-703.

Csoma, A.E., Goldstein, R.H., Mindszenty, A. \& Simone, L., 2004. Diagenetic salinity cycles and sea level along a major unconformity, Monte Camposauro, Italy. Journal of Sedimentary Research 6, 889-903.

Dawson, F.M., Kalkreuth, W.D. \& Sweet, A.R., 1994. Stratigraphy and coal resource potential of the Upper Cretaceous to Tertiary strata of northwestern Alberta. Geological Survey of Canada Bulletin 466, 60 pp.

Dutta, P., 1992. Climatic influence on diagenesis fluvial sandstones. [In:] K. Wolf \& G. Chillingrain (Eds): Diagenesis III. Developments in Sedimentology 47, 674 pp.

Ehrenberg, S.N., Aagaard, P., Wilson, M.J., Fraser, A.R., \& Duthie, D.M.L., 1993. Depth-dependent transformation of kaolinite to dickite in sandstones of the Norwegian continental shelf. Clay Minerals 28, 325-352.

Emery, D., Myers, K.J., \& Young, R., 1990. Ancient subaerial exposure and freshwater leaching in sandstones. Geology 18, 1178-1181. 
Garcia, A.J.V., 2000. Pre-Aptian unconformity in the Sergipe-Alagoas Basin (northeastern Brazil); an important control on the pre-rift reservoir sandstone porosity evolution. Brazil 31st International Geological Congress; Abstracts volume.

Grim, R. E., 1953. Clay mineralogy. McGraw-Hill Series in Geology, 377 pp.

Jerzykiewicz, T., 1997. Stratigraphic framework of the upper Cretaceous to Paleocene strata of the Alberta Basin. Geological Survey of Canada Bulletin 510, 121.

Jerzykiewicz, T. \& Langenberg, W., 1983. Structure, stratigraphy and sedimentology facies of the Paleocene and Lower Cretaceous coal-bearing strata in the Coalspur and Grande Cache areas, Alberta. Canadian Society of Petroleum Geologists Conference (The Mesozoic of Middle North America), Field Trip Guidebook, No. 9, 63.

Jerzykiewicz, T. \& Mclean, J.R., 1980. Lithostratigraphical and sedimentological framework of coal-bearing Upper Cretaceous and Lower Tertiary strata, Coal Valley area, central Alberta Foothills. Geological Survey of Canada, Paper 79-12, 47.

Jerzykiewicz, T. \& Sweet, A.R., 1986. The CretaceousTertiary boundary in the central Alberta Foothills. In; Stratigraphy. Canadian Journal of Earth Science 23, 1356-1374.

Jerzykiewicz, T. \& Sweet, A.R., 1988. Sedimentological and palynological evidence of regional climatic changes in the Campanian to Paleocene sediments of the Rocky Mountain Foothills, Canada. Sedimentary Geology 59, 29-76.

Jerzykiewicz, T., Lerbekmo, J.F. \& Sweet, A.R., 1984. The Cretaceous-Tertiaryboundary, central AlbertaFoothills. 1984 Canadian Paleontology and Biostratigraphy Seminar, Programme with Abstracts, 4.

Ketzer, J.M., Morad, S., Evans, S., Al-Aasm, I.S., 2002. Distribution of diagenetic alterations in fluvial, deltaic, and shallow marine sandstones within a sequence stratigraphic framework: evidence from the Mullaghmore Formation Formation (Carboniferous), NW Ireland. Journal of Sedimentary Research 72, 760774.

Ketzer, J.M., Holz, M., Morad, S., Al-Aasm, I.S., $2003 a$. Sequence stratigraphic distribution of diagenetic alterations in coalbearing, paralic sandstones: evidence from the Rio Bonito Formation (early Permian), southern Brazil. Sedimentology 50, 855- 877.

Ketzer, J.M., Morad, S. \& Amorosi, A., 2003b. Predictive diagenetic clay-mineral distribution in siliciclastic rocks within a sequence stratigraphic framework. [In:] R.H. Worden \& S. Morad (Eds): Clay Mineral Cements in Sandstones. International Association of Sedimentologists Special Publication 34, Blackwell Publication, Oxford, 43-61.

Lerbekmo,J.F.\&Sweet,A.R.,2008.Magnetobiostratigraphy of the continental Paleocence upper Coalspur and Paskapoo formations near Hinton, Alberta. Bulletin of Canadian Petroleum Geology 56, 118-146.

Longiaru, S., 1987. Visual comparators for estimating the degree of sorting from plane and thin sections. Journal of Sedimentary Petrology 57, 791-794.
Luebking, G., Longman, M. \& Carlisle, J., 2001. Unconformity related chert/dolomite production in the Pennsylvanian Amsden Formation, and the utilization of the drillstem test in finding hydrocarbons. American Association of Petroleum Geologists Annual Meeting, Expanded Abstracts, 121.

McCarthy, P.J. \& Plint, A.G., 1998. Recognition of interfluve sequence boundaries: integrating paleopedology and sequence stratigraphy. Geology 26, 387- 390.

Miall, A.D., 1997. The geology of stratigraphic sequences. Springer-Veralg, Berlin, $433 \mathrm{pp}$.

Morad, S., Ketzer, J.M., De Ros, L.F., 2000. Spatial and temporal distribution of diagenetic alterations in siliciclastic rocks: implications for mass transfer in sedimentary basins. Sedimentology 47, 95- 120.

Nurkowski, J.R., 1984. Coal quality, coal rank variation and its relation to reconstructed overburden, Upper Cretaceous and Tertiary plains coals, Alberta, Canada. American Association of Petroleum Geologists Bulletin 68, 285-295.

Pettijohn, F. J., Potter, P.E. \& Siever, R., 1987. Sand and sandstone. 2nd ed. Springer-Verlag, New York, 553 pp.

Posamentier, H. W., Jervey, M.T. \& Vail P.R., 1988. Eustatic controls on clastic deposition I: Conceptual framework. [In:] C.K. Wilgus, B.S. Hastings, C.G.St.C. Kendall, H.W. Posamentier, C.A. Ross. \& J.C. Van Wagoner (Eds): Sea level change: an integrated approach. SEPM Special Publication 42, 109-124.

Posamentier, H. W. \& Vail P.R., 1988. Eustatic controls on clastic deposition II: Sequence and systems tract models. [In:] C.K. Wilgus, B.S. Hastings, C.G.St.C. Kendall, H.W. Posamentier, C.A. Ross. \& J.C. Van Wagoner (Eds): Sea level change: an integrated approach. SEPM Special Publication 42, 125-154.

Robert, C. \& Chamley, H., 1991. Development of early Eocene warm climates, as inferred from clay mineral variations in oceanic sediments. Palaeogeography, Palaeoclimatology, Palaeoecology 89, 315-31.

Shanley, K.W. \& McCabe, P.J., 1994. Perspectives on the sequence stratigraphy of continental strata. American Association of Petroleum Geologists Bulletin 78, 544-568.

Shanmugam, G., 1990. Porosity prediction in sandstones using erosional unconformities. [In:] , I.D. Meshri \& P.J. Ortoleva (Eds): Prediction of reservoir quality through chemical modeling. American Association of Petroleum Geologists, Memoir 49, 1-23.

Shanmugam, G. \& Higgins, J.B., 1988. Porosity enhancement from chert dissolution beneath Neocomian unconformity, Ivishuk Formation, North Slope, Alaska. American Association of Petroleum Geologists Bulletin, 72, 523-535.

Shutov, V.D., Aleksandrova, A.V., \& Losievskaya, S.A., 1970. Genetic interpretation of the polymorphism of the kaolinite group in sedimentary rocks. Sedimentology $15,69-82$.

Suttner, J. \& Dutta, K., 1986. Alluvial sandstone composition and paleoclimate. II. Authigenic mineralogy. Journal of Sedimentary Petrology 56, 346358.

Tardy, Y., 1971. Characterization of the principal weathering types by the geochemistry of waters 
from some European and African crystalline massifs. Chemical Geology 7, 253271.

Velde, B., 1985. Clay minerals, a physico-chemical explanation of their occurrence. Developments in Sedimentology 4, Elsevier, New York, 427 pp.

Weaver, C.E., 1989. Clays, muds, and shales. Developments in Sedimentology 44, Elsevier, Amsterdam, 819 pp.

Wilson, M.D. \& Pittman, E.D., 1977. Authigenic clays in sandstones: recognition and influence on reservoir properties and paleoenvironmental analysis. Journal of Sedimentary Petrology 47, 3-31.

Wu, Y., Shouan, Z. \& Ai, H., 1998. Unconformity types and their relationship to oil/gasreservoirs in the Tarim Basin, Xinjiang, China. Xinjiang Petroleum Geology 19, 101-105.

Manuscript received 11 June 2009; revision accepted 16 November 2009. 